\title{
HTR Editorial
}

Taking over the role of editor for Harvard Theological Review is an enormous honor, an exciting opportunity, and of course a daunting task. The latter feeling in particular is made all the more vivid when one has to follow in the footsteps of two predecessors who are also two extremely distinguished scholars, as is the case for Jon Levenson and Kevin Madigan. In the course of the ten-year period of their tenure as co-editors of HTR, Levenson and Madigan have more than maintained the high standard of academic rigor and innovation that has characterized the journal through its long history. The two co-editors have also managed to expand the reach of the journal into new areas (such as Jewish and Islamic studies) to match a changed landscape within Harvard Divinity School and in the global study of religion more broadly. This difficult goal has been achieved while keeping up with a remarkable record of research and publications as well as the more mundane and often overlooked tasks of an editor, such as finding appropriate reviewers for difficult pieces or reading through the proofs of each new issue.

Jon D. Levenson is the Albert A. List Professor of Jewish Studies and the author of more than ten books and countless articles in the fields of Hebrew Bible, midrash studies, and Jewish theology. Levenson's scholarship combines in an effective and provocative way some traits that are quite difficult to find together in an academic world more and more subject to the strictures of specialization. Indeed, Levenson is equally able to analyze with philological and literary rigor the fine points of a biblical text as well as to contextualize such discussions within overarching trajectories of Jewish and Christian theology up to the present day. His contributions on themes as disparate as the doctrine of resurrection, the sacrifice of Isaac, or the controversial 
category of Abrahamic religions are required readings for scholars in the field of biblical studies and beyond.

Kevin J. Madigan is the Winn Professor of Ecclesiastic History and, right after leaving HTR, has just taken up another significant position at Harvard by becoming Faculty Dean of Eliot House with his wife and colleague, Professor Stephanie Paulsell. Madigan is a specialist of Medieval Christianity and has written extensively on the theological understanding of poverty, eschatological expectations, and anti-Judaism in the Middle Ages. Like Levenson, however, Madigan's scholarly expertise stretches far beyond this initial area of specialization. The two have actually co-authored a book (the important Resurrection: The Power of God for Christians and Jews) in 2008, but in more recent times Madigan has gone on to research and teach on the Holocaust in the context of the Catholic church. His next book (Antichrists in Our Day: Popes, Prelates, and Protestants in Fascist Italy, expected in 2020) will deal with the fascinating topic of Protestant denominations in Italy under the Fascist regime.

By looking at what Levenson and Madigan have accomplished through their tenure as editors of HTR, it becomes evident how challenging it is to follow in their path. But such a feeling acquires an entirely new dimension today, in the midst of times that are scary and uncertain to an unprecedented extent. We are all suffering in some ways from the perduring consequences of the Covid-19 pandemic, but there is little doubt that this catastrophe is impacting more tragically and painfully people who are already socially and economically marginalized. The effects of the crisis are visible all around us and even an academic journal like HTR is no exception. As many others have noted in other venues, even over the very few months in which I have begun to serve in my current position it has been easy for me to notice a significant increase in the overall number of submissions. This change, however, has been accompanied by a correspondent decrease in the number of articles submitted by women or other authors belonging to minoritized groups. This is only a symptom of a general problem faced by academic institutions all over the world and surely a single journal cannot solve it by itself. However, all the editorial board and staff of HTR are cognizant of such a worrying trend and are hard at work to figure out strategies and solutions to counteract it.

Being the editor of Harvard Theological Review is both a responsibility and an honor. This is all the more true for someone, like me, who has looked at this journal as an example of rigorous and energizing scholarship even before I could think about moving to North America, let alone becoming editor of HTR. I remember quite well how significant it was for me (as an undergraduate encountering the critical study of biblical texts for the first time) to find in the library and on the pages of HTR surprising and exhilarating new readings of passages I thought I had known practically my entire life. I am sure that this experience of mine has been and is currently shared by many scholars all over the world. It is not by chance that, in its long history, HTR has had several non-American editors, who in their turn have 
also been scholars capable of leaving a long-lasting mark on the development of the discipline (as, for instance, Krister Stendahl or François Bovon). Still now HTR is chosen by scholars all over the world as the journal to which they submit their most creative work. A very prominent task for the incoming years will be to take advantage of HTR's global reach in order to make it even more of an efficient conduit for far-reaching conversations in the study of religion.

Harvard Theological Review has been for many years (and by design) the place to showcase the variety and the creativity of the academic work carried on at Harvard Divinity School. In more recent times, it must be admitted that the changes occurring at HDS (and in the nature of the study of religion at Harvard more broadly conceived) had not been reflected as clearly in the journal. Levenson and Madigan, through a deliberate and remarkable effort, succeeded in starting a significant change, so that even now HTR has acquired a notable standing in fields (such as Jewish and Islamic studies) with which the journal was not traditionally associated. As the new editor, I hope to continue this trend in order to move progressively the journal more into line with the current configuration of Harvard Divinity School. Indeed, the School has enormous strengths (both in its faculty and in its student body) that deserve to be recognized for their creativity and intellectual sophistication.

Let me finish this introduction with renewed thanks to Jon Levenson and Kevin Madigan for their exceptional service to HTR and with wholehearted wishes to all the readers of the journal for health and serenity in these difficult times.

Giovanni B. Bazzana 